\title{
Report on Scoping the Apparel Manufacturing Enterprise
}

Howard T. Moncarz

Tina Y. Lee

U.S. DEPARTMENT OF COMMERCE

Technology Administration

National Institute of Standards

and Technology

Manufacturing Engineering Laboratory

Factory Automation Systems Division

Gaithersburg, MD 20899

$\mathrm{QC}$

100

.456 



\section{Report on Scoping the Apparel Manufacturing Enterprise}

Howard T. Moncarz

Tina Y. Lee

U.S. DEPARTMENT OF COMMERCE

Technology Administration

National Institute of Standards

and Technology

Manufacturing Engineering Laboratory

Factory Automation Systems Division

Gaithersburg, MD 20899

January 1993

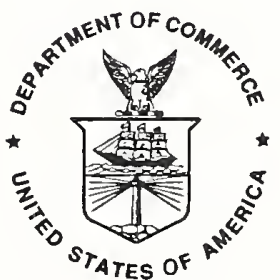

U.S. DEPARTMENT OF COMMERCE

Barbara Hackman Franklin, Secretary

TECHNOLOGY ADMINISTRATION

Robert M. White, Under Secretary for Technology

NATIONAL INSTITUTE OF STANDARDS

AND TECHNOLOGY

John W. Lyons, Director 



\title{
Report on Scoping the Apparel Manufacturing Enterprise
}

\author{
Howard T. Moncarz and Y. Tina Lee \\ Factory Automation Systems Division \\ Manufacturing Engineering Laboratory \\ National Institute of Standards and Technology \\ Gaithersburg, MD 20899
}

\begin{abstract}
This paper identifies a set of manufacturing data interfaces that could be standardized for the effective computer integration of the information required to operate an apparel manufacturing enterprise. The interfaces are called Application Protocols. A method is described to use pieces of information, referred to as Units of Functionality, as building blocks for designing Application Protocols.
\end{abstract}

\section{KEYWORDS}

AMA; APDES; apparel; application protocol; enterprise framework; pattern; PDES; STEP; unit of functionality 


\section{,}




\section{TABLE OF CONTENTS}

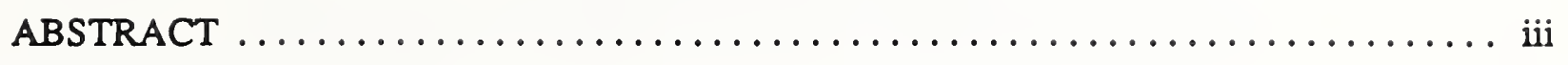

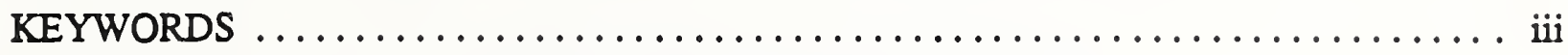

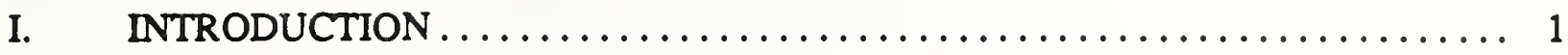

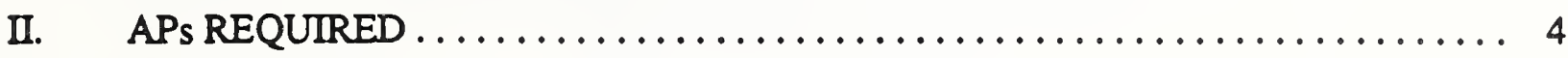

III. MAPPING THE APs TO THE AMA $\ldots \ldots \ldots \ldots \ldots \ldots \ldots \ldots \ldots \ldots$

IV. UNITS OF FUNCTIONALITY AS BUIIDING BLOCKS FOR APs .......... 9

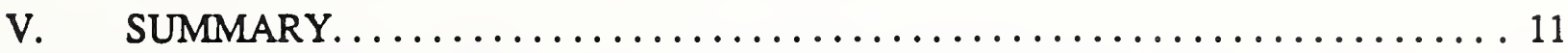

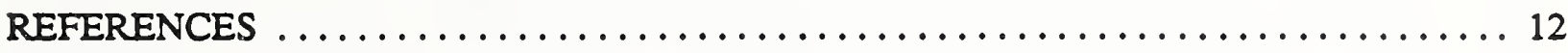

APPENDIX A. MAPPING THE APS TO THE ACTIVITY MODEL $\ldots \ldots \ldots \ldots \ldots 13$

APPENDIX B. MAPPING THE ACTIVITY MODEL TO THE APS .......... 17

APPENDIX C. MAPPING THE INFORMATION MODEL TO THE APs ......... 18

APPENDIX D. MAPPING THE APS TO THE INFORMATION MODEL .......... 26

D.1 Mapping the APs to the Information Model Views .............. 26

D.2 Mapping the APs to the Entities ....................... 26 



\title{
Report on Scoping the Apparel Manufacturing Enterprise
}

\author{
Howard T. Moncarz and Y. Tina Lee \\ Factory Automation Systems Division \\ Manufacturing Engineering Laboratory \\ National Institute of Standards and Technology \\ Gaithersburg, MD 20899
}

\section{INTRODUCTION}

The apparel industry has used computers to great advantage to automate many of its manufacturing processes. However, the manufacturing innovations often stand alone as "islands of automation." Integrating the separate automated processes could greatly improve the effectiveness of the entire enterprise. This paper identifies a set of manufacturing data interfaces that could be standardized for the effective computer integration of the information required to operate an apparel manufacturing enterprise.

Two technology enablers are necessary to foster the development of integration. The first is an enterprise framework that specifies the entire functionality of an enterprise's operation. The second is a set of manufacturing data standards that specifies the interfaces among these functions. This paper specifies a possible set of manufacturing data standards, based on an analysis of a previously proposed enterprise framework.

A straw man for an enterprise framework for apparel manufacturing has been developed under sponsorship of the Defense Logistics Agency (DLA) by the Georgia Institute of Technology [Jay1, Jay2]. This framework is referred to as the Apparel Manufacturing Architecture (AMA). The AMA is a "to be" framework that represents an apparel manufacturing enterprise of the future. It is defined in terms of an activity model that represents the functions required and an information model composed of entities that are used by these functions. The activities and information requirements are represented using the modeling methodologies IDEF0 [USAir1] and IDEF1x [USAir2], respectively.

Once an enterprise framework is recognized as a standard, interfaces among all functions associated with that framework can be identified and standardized as well. These are known as open system standards, because they promote the development of alternative products for each of the functions. Each product may be unique, but each has the characteristic that it is "plug compatible" into the open system. A straw man for this set of manufacturing data standards can be based on the Standard for the Exchange of Product Model Data (STEP).

STEP is an emerging international standard ${ }^{1}$ for representing product data throughout a product's life cycle. In the U.S., an effort has been undertaken to support and accelerate STEP's objectives, and to ensure that the requirements of U.S. industry are incorporated into STEP. This effort is called PDES (Product Data Exchange using STEP). Many of the information requirements as well as the software tools being developed to support STEP are applicable for any manufacturing industry. To serve the needs for a particular industry, Application Protocols (APs) are developed

\footnotetext{
${ }^{1}$ Refer to ISO 10303-1, Industrial Automation Systems and Integration-Product Data Representation and Exchange-Overview and Fundamental Principles, to be published.
} 
that designate the specific information and application requirements for that industry. The APs draw upon integrated resources ${ }^{2}$ to share the same information among different APs.

The National Institute of Standards and Technology (NIST) has been working on a project to develop a suite of APs to support computer integration of the apparel product life cycle. This project is sponsored by DLA, and the work is being carried out in cooperation with the Computer Integrated Manufacturing Committee of the American Apparel Manufacturers Association (AAMA). The project has been named the Apparel Product Data Exchange Standard (APDES) project.

The APDES project is part of a substantial program sponsored by DLA to improve apparel manufacturing technology. The DLA program is advancing technology from traditional sizebased methods (ready-to-wear) to methods that use body measurement data directly (made-tomeasure). Additionally, the program is advancing production methods from fixed procedures based on standard products to flexible, computer-integrated manufacturing using product representation standards to communicate requirements. The new technologies developed will lead to better fit, higher product quality, economical unit-production methods, and quick response. All told, the program is a broad evolution toward integrated enterprises, in which all phases of a product's life cycle are coordinated through a framework of standards, concurrent engineering practice, and supporting technology. ${ }^{3}$

The goal for the APDES project is to develop manufacturing data standards based on STEP that will support integration of the projects that DLA is sponsoring. The first objective, when the APDES project began, was to demonstrate the feasibility of using STEP for apparel. The objective was accomplished by developing an information model for pattern data using STEP technology [Lee1]. The information model was represented in the EXPRESS modeling language [ISO11]. The model was implemented in a computer program that exchanges pattern data between two proprietary industry formats [Moncarz]. A neutral set of data structures, based on the information model developed, was used as the intermediary in this process. It was concluded that STEP APs can provide the information interfaces to integrate the apparel product life cycle.

The timeline required for integrating the DLA-sponsored research projects is insufficient to enable the development and integration of formal STEP APs. A formal STEP AP that is developed according to ISO guidelines [Palmer] requires an extensive, consensus gathering effort. Instead, a suite of "prototype" APs will be developed (in the short term) for the APDES project. ${ }^{4}$ A prototype AP will not require industry consensus, and it will consist of four main components:

Scope: general description of the information requirements and the applications supported

Application Reference Model (ARM): an information model that formally describes the information requirements and constraints for an application domain. The model uses application-specific terminology and rules familiar to an expert from the application domain. The model is independent of any physical implementation.

\footnotetext{
2Integrated resources are "a set of STEP Parts [separate documents in the STEP (ISO 10303) series] which provide application-independent information models for widely-used types of information. Integrated resources support communication between diverse applications by providing an agreed upon set of definitions and meanings for data that are independent of specific application requirements" [Kramer].

${ }^{3}$ Selected papers from DLA's sponsored apparel research are published in the annual Academic Apparel Research Conference proceedings. The most recent conference was held February 17-18, 1992 [DLA].

${ }^{4}$ NIST is concurrently working on the development of formal STEP APs for the apparel industry [Lee2].
} 
In a prototype AP, the ARM is expressed in the formal computer language, EXPRESS, and is used in implementing the application interfaces 5

Conformance Testing (CT) Requirements: testing requirements to demonstrate that an application that incorporates the prototype AP does so correctly

Usage Guide: a manual that contains a written description of the Scope, the Application Reference Model, and the Conformance Testing Requirements to enable a developer to implement the AP into an application

A formal STEP AP requires one more component:

Application Interpreted Model (AIM): "a model that describes the interpretation of the integrated resource constructs that provide functional equivalence to the AP's information requirements as specified in the application reference model. The form of an AIM is an EXPRESS schema" [Palmer].

The AIM will not be included in the prototype APs developed, in order to expedite the development of the prototype APs. In the long term, the prototype APs will serve as straw man APs to help in the development of formal STEP APs for the apparel industry. The formal STEP APs will be developed in full conformance with STEP standards, including the attainment of industry consensus as required by STEP procedures.

5 In a formal STEP AP, the ARM can be described in one of three information modeling languages (EXPRESS, NIAM [Nijssen], or IDEFlx), and is developed from the point of view of the application domain, without regard to the rest of STEP's resources. It is then mapped to the AIM, which is written in EXPRESS, and uses constructs from the STEP integrated resources. An application that implements the AP will be based directly on the EXPRESS version of the AIM. 


\section{APS REQUIRED}

It is important to identify the set of APs that will be needed for the entire apparel manufacturing enterprise before beginning the actual development of particular APs. Identifying the entire set of APs in advance provides a plan for developing them and allowing for the effective "interoperability" among the AP implementations. In particular, the APs that are determined to have the greatest industry impact can be assigned the highest priorities for development. Furthermore, knowing how a particular AP fits into the "big picture" is helpful for developing that AP.

The set of APs was identified mainly by studying the AMA - in particular the DEFO and IDEF1x diagrams. The goal was to determine a set of APs that supported all of the functions identified in the IDEFO diagrams and provided all of the information entities identified in the IDEF1x diagrams. Additionally, knowledge of industry needs in general and DLA needs in particular were considered in identifying the set of APs. For example, the ready-to-wear pattern making AP has application in currently available pattern making CAD systems. The made-tomeasure pattern making AP has application for new systems that are being developed for the future.

In all, fifteen APs were identified:

- Ready-to-wear pattern making

- Made-to-measure pattern making

- Garment style development

- Marker making and cutting

- Sewing and assembly

- Cost estimation

- Quality control

- Manufacturing planning

- Production scheduling

- Packing and shipping

- Material procurement

- Manufacturing resource maintenance

- Production resource allocation

- Sales and marketing

- Inventory maintenance.

It is recognized that the AMA is a straw man, and that changes and enhancements to it are expected before the AMA is accepted by industry. Nevertheless, the current version of the AMA provides a sufficiently comprehensive model for determining a set of APs that can be used to integrate the apparel manufacturing enterprise. The APDES project team is in close contact with the AMA developer and will address the consequences of AMA modifications to the APDES project as warrainted.

The list of APs, showing the activities supported by each and the information requirements provided by each, is shown in Table 1 on pages 6 and 7 . 
Table 1. Application Protocols for an Apparel Manufacturing Enterprise

\begin{tabular}{|c|c|c|}
\hline $\begin{array}{l}\text { Application } \\
\text { Protocol }\end{array}$ & Activities Supported & Information Requirements \\
\hline $\begin{array}{l}\text { Ready-to-wear } \\
\text { pattern making }\end{array}$ & $\begin{array}{l}\text { Create or modify the pattern } \\
\text { pieces that make up a } \\
\text { garment for a particular size, } \\
\text { and grade the pattern pieces } \\
\text { for other sizes. }\end{array}$ & $\begin{array}{l}\text { Pattern piece specifications for a particular } \\
\text { garment type, style, and size; grading rules to } \\
\text { modify the basic pattern pieces to fit other } \\
\text { specified sizes }\end{array}$ \\
\hline $\begin{array}{l}\text { Made-to- } \\
\text { measure pattern } \\
\text { making }\end{array}$ & $\begin{array}{l}\text { Create or modify the pattern } \\
\text { pieces that make up a } \\
\text { garment for a particular set of } \\
\text { body measurements. }\end{array}$ & $\begin{array}{l}\text { Pattern piece specifications for a particular } \\
\text { garment type, style, and set of body } \\
\text { measurements-more comprehensive than the } \\
\text { typical one or two measurements that } \\
\text { characterize the size for ready-to-wear apparel }\end{array}$ \\
\hline $\begin{array}{l}\text { Garment style } \\
\text { development }\end{array}$ & $\begin{array}{l}\text { Create or modify a garment's } \\
\text { style. }\end{array}$ & $\begin{array}{l}\text { Garment shape, fit, materials, and the general } \\
\text { construction features that specify the style } \\
\text { concept; customer requirements }\end{array}$ \\
\hline $\begin{array}{l}\text { Marker making } \\
\text { and cutting }\end{array}$ & $\begin{array}{l}\text { Based on production orders, } \\
\text { create markers from pattern } \\
\text { pieces, and use those markers } \\
\text { to create cut parts. } \\
\end{array}$ & $\begin{array}{l}\text { Pattern piece shapes, orientation constraints to } \\
\text { fabric; production orders; information required } \\
\text { to create markers to be used for cutting fabric; } \\
\text { information characterizing the cut parts }\end{array}$ \\
\hline $\begin{array}{l}\text { Sewing and } \\
\text { Assembly }\end{array}$ & $\begin{array}{l}\text { Sew separate pattern pieces } \\
\text { together, attach trims and } \\
\text { accessories, and do other } \\
\text { stitching, such as decorative } \\
\text { stitching, as required. }\end{array}$ & $\begin{array}{l}\text { Information used for assembly of cut pattern } \\
\text { pieces-includes piece-to-piece relationships, } \\
\text { seam allowances, type of stitching for } \\
\text { assembly, as well as any other stitching } \\
\text { required, such as decorative stitching; } \\
\text { specifications for how all the garment sub- } \\
\text { assemblies, including trims and accessories, } \\
\text { are related }\end{array}$ \\
\hline Cost estimation & $\begin{array}{l}\text { Estimate the cost for } \\
\text { manufacturing a particular } \\
\text { number of garments. }\end{array}$ & $\begin{array}{l}\text { Amount and type of fabric; construction } \\
\text { details, including materials; manufacturing } \\
\text { procedures; material and labor costs; costing } \\
\text { information obtained from producing a sample } \\
\text { garment }\end{array}$ \\
\hline Quality control & $\begin{array}{l}\text { Establish quality control } \\
\text { standards, inspect materials } \\
\text { and finished garments, and } \\
\text { take corrective action on } \\
\text { rejected materials or finished } \\
\text { goods. }\end{array}$ & $\begin{array}{l}\text { Quality standards and inspection data-to } \\
\text { provide in-process quality control, as well as } \\
\text { quality assurance reports, at critical } \\
\text { manufacturing areas-including fabric and } \\
\text { other material inspections, completed garment } \\
\text { inspections, and other inspections at important } \\
\text { intermediate stages of manufacturing }\end{array}$ \\
\hline
\end{tabular}


Table 1. Application Protocols for an Apparel Manufacturing Enterprise (continued)

\begin{tabular}{|c|c|c|}
\hline $\begin{array}{l}\text { Application } \\
\text { Protocol }\end{array}$ & Activities Supported & Information Requirements \\
\hline $\begin{array}{l}\text { Manufacturing } \\
\text { planning }\end{array}$ & $\begin{array}{l}\text { Create process plans for } \\
\text { manufacturing particular } \\
\text { garments, taking into account } \\
\text { the capabilities of the factory. }\end{array}$ & $\begin{array}{l}\text { Process planning information-includes } \\
\text { identification of the fabrics, construction } \\
\text { materials, and manufacturing procedures used } \\
\text { for manufacturing a particular garment; } \\
\text { specifications for sequencing manufacturing } \\
\text { operations }\end{array}$ \\
\hline $\begin{array}{l}\text { Production } \\
\text { scheduling }\end{array}$ & $\begin{array}{l}\text { Schedule production } \\
\text { operations. }\end{array}$ & $\begin{array}{l}\text { Specifications for manufacturing operations } \\
\text { and production orders; equipment and } \\
\text { employee availability }\end{array}$ \\
\hline $\begin{array}{l}\text { Packing and } \\
\text { shipping }\end{array}$ & $\begin{array}{l}\text { Pack finished goods and } \\
\text { distribute them, either to the } \\
\text { customer or to inventory. }\end{array}$ & $\begin{array}{l}\text { Information required to pack finished goods } \\
\text { and distribute them, either to the customer or } \\
\text { to inventory-includes customer requirements, } \\
\text { shipping orders, container requirements, stock } \\
\text { of containers and finished goods }\end{array}$ \\
\hline $\begin{array}{l}\text { Material } \\
\text { procurement }\end{array}$ & $\begin{array}{l}\text { Determine suitable vendors, } \\
\text { and procure materials needed } \\
\text { for production. }\end{array}$ & $\begin{array}{l}\text { Material sources, material requirements for a } \\
\text { production period, and procurement status }\end{array}$ \\
\hline $\begin{array}{l}\text { Manufacturing } \\
\text { resource } \\
\text { maintenance }\end{array}$ & $\begin{array}{l}\text { Maintain the information } \\
\text { characterizing the factory's } \\
\text { equipment and human } \\
\text { resource capabilities. }\end{array}$ & $\begin{array}{l}\text { Characteristics of a plant's manufacturing } \\
\text { resources in terms of equipment capacity, } \\
\text { employees, and employee skill levels }\end{array}$ \\
\hline $\begin{array}{l}\text { Production } \\
\text { resource } \\
\text { allocation }\end{array}$ & $\begin{array}{l}\text { Assign manufacturing } \\
\text { location, equipment, and } \\
\text { operators for a particular } \\
\text { production program. }\end{array}$ & $\begin{array}{l}\text { Information to match employees to equipment } \\
\text { according to equipment capabilities, employee } \\
\text { skill levels, and plant scheduling; plant } \\
\text { capacity }\end{array}$ \\
\hline $\begin{array}{l}\text { Sales and } \\
\text { marketing }\end{array}$ & $\begin{array}{l}\text { Determine customer } \\
\text { requirements, and solicit } \\
\text { orders. }\end{array}$ & $\begin{array}{l}\text { Customer requirements, style, fabric; customer } \\
\text { orders, production and delivery schedules }\end{array}$ \\
\hline $\begin{array}{l}\text { Inventory } \\
\text { maintenance }\end{array}$ & $\begin{array}{l}\text { Maintain inventories of } \\
\text { materials and finished goods. }\end{array}$ & $\begin{array}{l}\text { Information required for storing, retrieving, } \\
\text { and dispatching materials and finished goods }\end{array}$ \\
\hline
\end{tabular}




\section{MAPPING THE APs TO THE AMA}

The AMA is defined in terms of a functional framework and an information model composed of entities that are used by these functions. The functions represented in the activity model that are supported by each of the APs have been determined. All of the functions incorporated in the AMA activity model are mapped to the set of APs identified. The mapping of the APs to the functions in the activity model is shown in Appendix A. The reverse mapping (i.e. how the functions in the activity model map back to each of the APs) is shown in Appendix B.

The particular AMA functions grouped with each AP gives the reader an idea of the type of functions each AP supports. A one-to-one correspondence between AMA functions and the actual AP functions is not intended.

The parts (or views) of the information model and the entities that are incorporated by each of the APs have also been determined. The mapping of the information model to the APs is shown in Appendix C. All of the information model views and entities in the AMA are mapped to the set of APs identified. The APs provide complete coverage of the AMA, in terms of the AMA's information model.

The particular AMA entities grouped with each AP gives the reader an idea of the type of entities each AP uses. A one-to-one correspondence between AMA entities and the actual AP entities is not intended.

The reverse mapping (i.e. how the APs map back to each information model view and each entity) is shown in Appendix D. The reverse mapping is useful to help determine what pieces of information span more than one AP. That knowledge will be helpful in determining Units of Functionality, the subject of the next section. 


\section{UNITS OF FUNCTIONALITY AS BUILDING BLOCKS FOR APS}

Currently, NIST is developing the ready-to-wear pattern making AP. This AP is based on an updated version of the apparel pattern information model previously developed by NIST. Much of the effort expended for developing this AP will be leveraged in developing succeeding APs, as a consequence of defining "Units of Functionality." A Unit of Functionality (UoF) is composed of a group of entities that can be associated together to form a single concept within the context of an AP. Hence, an AP is composed of a collection of UoFs. A good candidate for a UoF is a unit of information that can be shared among two or more APs. Choosing UoFs in this manner simplifies integration of those APs, and leverages the effort of developing multiple APs.

A discussion of the reasoning used to determine a set of UoFs to use for two of the APs should clarify how UoFs are selected. A set of UoFs that will be used to design the ready-to-wear and the made-to-measure pattern making APs have been determined. These UoFs and their meanings follow:

UoF
pattern
size
grading

fit

\author{
Meaning \\ collection of pattern pieces that make up a style \\ one or more designations that identify the size of a pattern \\ information that can be used to modify a pattern of a particular size \\ to other sizes \\ collection of anthropometric measurements used to determine the \\ dimensions of a pattern
}

These two APs will be composed of the following UoFs:
AP
ready-to-wear pattern making
made-to-measure pattern making
UoFs
pattern, grading, size
pattern, fit

The particular composition of UoFs for these two APs was carefully chosen. The pattern UoF, which includes all the information that is necessary for its specification and testing, will be used in its entirety in the ready-to-wear and the made-to-measure pattern making APs. It will also be used in other APs where pattern shape information is important.

With proper application software, the grading UoF will provide information to transform the pattern UoF to other sizes. The grading UoF will reference the pattern UoF and the size UoFs to which it applies.

The size UoF was made a separate UoF for several reasons. A ready-to-wear garment is given a size designation based on one or two dimensions of the garment (generally, one longitudinal dimension and one circumferential dimension). Unfortunately, the dimensions used for a particular size designation are arbitrary and vary from manufacturer to manufacturer, as well as from country to country. A size designation without additional information is not complete to unambiguously represent the size of a particular garment. Currently, the European community is working to develop size standards for ready-to-wear apparel that will be more complex, though more reliable, than existing sizing systems [Palaganas]. The information that characterizes a size can be represented separately from the information in the pattern and grading UoFs. If the internal structure of the size UoF needs to be changed, the pattern and grading UoFs will not be affected.

Furthermore, the size UoF (for a ready-to-wear garment) will have similar types of entities as the fit UoF (for a made-to-measure garment). This similarity will simplify communications 
involving data conversions and/or data sharing between ready-to-wear and made-to-measure applications.

UoFs will continually be defined as the APs development effort proceeds. Defining UoFs carefully will allow multiple APs to share the same UoFs. In this way, the UoFs can be considered building blocks for developing application interfaces. 


\section{SUMMARY}

Fifteen application areas for AP development have been identified within the framework of the AMA.

Currently, NIST is developing the ready-to-wear pattern making AP. This AP is based on an updated version of the information model previously developed by NIST [Lee1]. Much of the effort expended for developing this AP will be leveraged in developing succeeding APs. The leveraging is a consequence of defining units of functionality and using them as building blocks for AP development.

The interface specifications developed in the APDES project are intended to be used in support of the apparel manufacturing research projects that DLA is supporting, to help in integrating those projects within the AMA. For a proposed STEP AP to be approved by the official STEP sanctioning organization-the International Organization for Standardization-an extensive, consensus gathering effort in the industry must be undertaken. The set of APs defined, the UoFs identified, and the APs that are currently being developed in the APDES project can be used as "straw men" for developing official STEP standards for apparel. 
[DLA] Defense Logistics Agency, Third Annual Academic Apparel Research Conference, Manufacturing Technology Information Analysis Center, 10 West 35th Street, Chicago, II 60616-3799, February 1992.

[ISO11] ISO DIS 10303-11, Product Data Representation and Exchange - Part 11: The EXPRESS Language Reference Manual, August 1992.

[Jay1] Jayaraman, S. and Malhotra, R., Apparel Manufacturing Architecture [Version 1.0], Volume 1: The Function and Dynamics Models, Draft, Georgia Institute of Technology, Research sponsored by U.S. Defense Logistics Agency, DLA90087-D-0018 CLIN 0007, October 1992.

[Jay2] Jayaraman, S. and Malhotra, R., Apparel Manufacturing Architecture [Version 1.0], Volume 2: The Information Model, Draft, Georgia Institute of Technology, Research sponsored by U.S. Defense Logistics Agency, DLA900-87-D-0018 CLIN 0007, October 1992.

[Kramer] Kramer, T. R., et al., Issues and Recommendations for a STEP Application Protocol Framework, NISTIR 4755, National Institute of Standards and Technology, Gaithersburg, MD, January 1992.

[Lee1] Lee, Y. T., On Extending the Standard for the Exchange of Product Data to Represent Two-Dimensional Apparel Pattern Pieces, NISTIR 4358, National Institute of Standards and Technology, Gaithersburg, MD, June 1990.

[Lee2] Lee, Y. T., "Apparel Product Data Exchange Standard," Proceedings of the Third Annual Academic Apparel Research Conference on Implementing Advanced Technology, Atlanta, GA, February 1992.

[Moncarz] Moncarz, H. T. and Lee, Y. T., Apparel STEP Translator, NISTIR 4612, National Institute of Standards and Technology, Gaithersburg, MD, June 1991.

[Nijssen] Nijssen, G. M. and Halpin, T. A., Conceptual Schema and Relational Database Design: A Fact Oriented Approach, Prentice Hall, 1989.

[Palaganas] Palaganas, D., "Uni-Sizing Europe," Apparel Industry Magazine, Atlanta, GA, September, 1991.

[Palmer] Palmer, M., Guidelines for the Development and Approval of STEP Application Protocols, ISO TC184/SC4/WG4 N 25 (P5), ISO, September 1991.

[USAir1] U.S. Air Force Wright Aeronautical Laboratories, Function Modeling Manual (IDEF0), Integrated Computer-Aided Manufacturing (ICAM) Architecture Part II, Volume IV, Materials Laboratory, U.S. Air Force Wright Aeronautical Laboratories, June, 1981.

[USAir2] U.S. Air Force Wright Aeronautical Laboratories, Information Modeling Manual IDEF1-Extended (IDEF1x), Report AFWAL-TR-86-4006, Volume 5, Part 4, Manufacturing Technology Directorate, U.S. Air Force Wright Aeronautical Laboratories, 1986. 


\section{APPENDIX A. MAPPING THE APS TO THE ACTIVITY MODEL}

This appendix details how the set of APs specified by this paper maps to the AMA's activity model, presented in the AMA report [Jay1]. The activity model is a hierarchical model-its functions are represented in multiple levels of decomposition. Many of the functions represented in the model can be decomposed into lower level functions.

The table below consists of three columns. The first column lists the activity model function number that is defined in the AMA report. If a function is decomposed into lower level functions, those functions are indented. The second column is a description of the function, taken verbatim from the AMA report. The third column gives an abbreviation for the AP that supports that activity model function. An AP is specified for an activity model function, only if that function has no further decompositions in the AMA model. If the function can be further decomposed, the third column contains a dash ('-').

Activity Number

A- 0

A0

A1

A11

A111

A112

A113

A114

A12

A121

A122

A1221

A1222

A1223

A123

A1231

A1232
Description

Operate an Apparel Manufacturing Enterprise (Context)

Operate an Apparel Manufacturing Enterprise

Develop and Market Garments

Market Style Ideas to Customers

Create Style Portfolios

Contact Potential Customers

Market Style Concepts

Develop Style Concept for Customer

Develop Garment Style

Control Style Development

Develop Construction Detail

Identify Garment Features

Assign Construction Materials

Develop Construction Features

Develop Garment's Shape

Develop Garment's Fit

Develop Grade Rules
AP

Abbrey.

${ }^{6}$ The following abbreviations for the selected APs are used in Appendices A, C, and D:

$\quad$ Eull Name of AP
ready-to-wear pattern making
made-to-measure pattern making
garment style development
marker making and cutting
sewing and assembly
cost estimation
quality control
manufacturing planning
production scheduling
packing and shipping
material procurement
manufacturing resource maintenance
production resource allocation
sales and marketing
inventory maintenance

Eull Name of AP

ready-to-wear pattern making made-to-measure pattem making

sewing and assembly

cost estimation

packing and shipping

material procurement

manufacturing resource maintenance

sales and marketing

inventory maintenance

Abbreviation of AP
grading
pattern
style
marker
assembly
cost
quality
planning
scheduling
packing
procurement
resources
allocation
sales
inventory

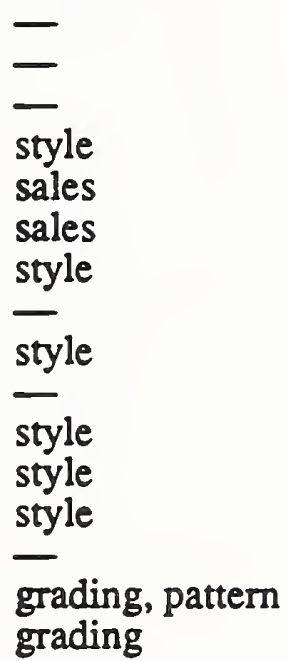




\begin{tabular}{|c|c|c|}
\hline $\begin{array}{c}\text { A1233 } \\
\text { A1234 } \\
\text { A13 } \\
\text { A131 } \\
\text { A132 } \\
\text { A133 } \\
\text { A14 } \\
\text { A141 } \\
\text { A1411 } \\
\text { A1412 } \\
\text { A1413 } \\
\text { A142 } \\
\text { A1421 } \\
\text { A1422 } \\
\text { A1423 } \\
\text { A1424 } \\
\text { A143 } \\
\text { A15 } \\
\text { A21 } \\
\text { A211 } \\
\text { A212 } \\
\text { A213 } \\
\text { A3342 } \\
\text { A343 } \\
\text { A3431 } \\
\text { A3421 } \\
\text { A3433 } \\
\text { A222 } \\
\text { A223 } \\
\text { A23 } \\
\text { A231 } \\
\text { A232 } \\
\text { A233 } \\
\text { A234 } \\
\text { A3 } \\
\text { A31 } \\
\text { A311 } \\
\text { A312 } \\
\text { A313 } \\
\text { A32 } \\
\text { A33 } \\
\text { A331 } \\
\text { A333 } 33 \\
\text { A334 } \\
\text { A345 } \\
\text { A3 } \\
\text { A3 }\end{array}$ & 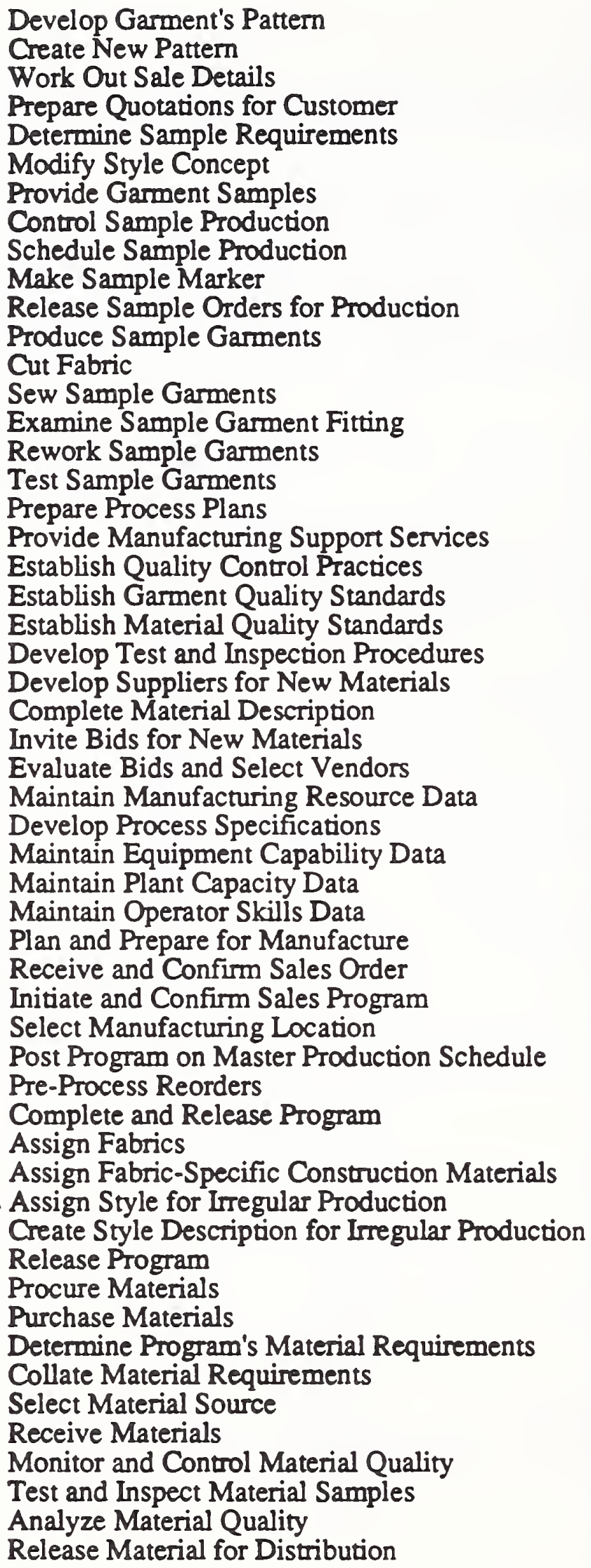 & $\begin{array}{l}\text { grading, patt } \\
\text { grading, patt } \\
\text { cost } \\
\text { sales } \\
\text { sales } \\
\text { - } \\
\text { scheduling } \\
\text { marker } \\
\text { allocation } \\
\text { - } \\
\text { marker } \\
\text { assembly } \\
\text { quality } \\
\text { quality } \\
\text { quality } \\
\text { planning } \\
\text { - } \\
\text { quality } \\
\text { quality } \\
\text { quality } \\
\text { - } \\
\text { procurement } \\
\text { procurement } \\
\text { procurement } \\
\text { - } \\
\text { resources } \\
\text { resources } \\
\text { resources } \\
\text { resources } \\
\text { - } \\
\text { quality } \\
\text { quality } \\
\text { quality } \\
\text { allocation } \\
\text { scheduling } \\
\text { sales } \\
\text { procurement } \\
\text { planning } \\
\text { planning } \\
\text { planning } \\
\text { planning } \\
\text { planning } \\
\text { - } \\
\text { procurement } \\
\text { procurement }\end{array}$ \\
\hline
\end{tabular}




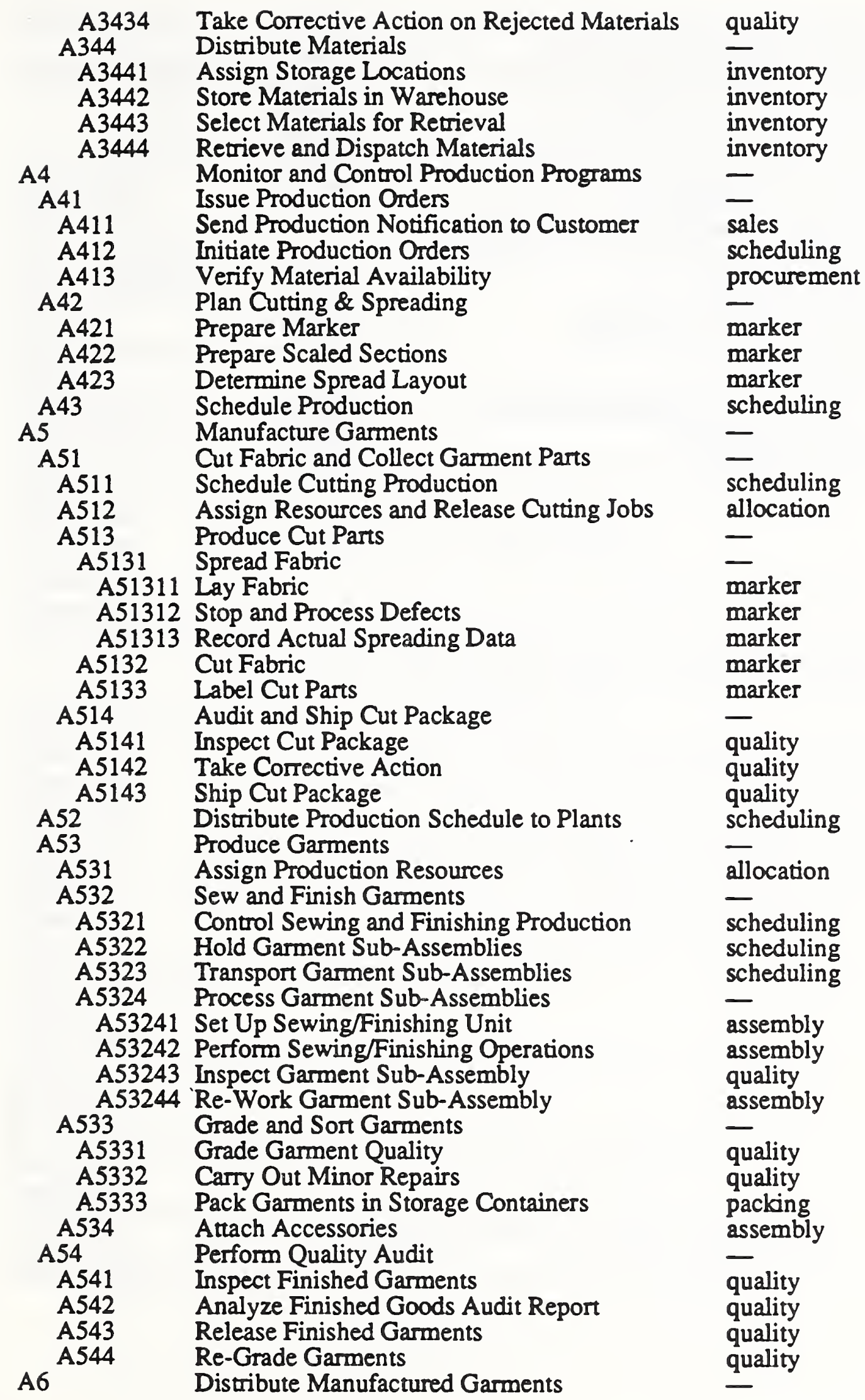


A61 Receive and Stock Garments

A611 Receive Garments in Warehouse

inventory

A612 Assign Storage Locations

A613 Move Garments to Storage

A614 Restock Leftovers from Packing

A62

A63

Dispose Irregular Garments

inventory

inventory

inventory

packing

Receive and Consolidate Shipping Orders

A64

Pack and Ship Garments

A641 Schedule and Control Packing Operations

packing

A6411 Prepare Packing Schedule

A6412 Assign Resources

A6413 Select Garments for Packing

A6414 Retrieve Garments for Packing

A642

Pack Garments

A6421 Load Picking Stations

A6422

Collect Garments and Pack in Cartons

A6423 Seal and Sort Cartons

A643

Release Shipments

packing

packing

packing

packing

packing

packing

packing

packing 
APPENDIX B. MAPPING THE ACTIVITY MODEL TO THE APS

The mapping presented in this appendix is the reverse of that in Appendix A. In this appendix, the activity model functions are mapped to each of the APs.

\begin{tabular}{|c|c|}
\hline $\begin{array}{l}\text { Application } \\
\text { Protocol }\end{array}$ & Activity Model Functions \\
\hline $\begin{array}{l}\text { Ready-to-wear } \\
\text { pattern making }\end{array}$ & $\mathrm{A} 1231, \mathrm{~A} 1232, \mathrm{~A} 1233, \mathrm{~A} 1234$ \\
\hline $\begin{array}{l}\text { Made-to- } \\
\text { measure pattern } \\
\text { making }\end{array}$ & A1231, A1233, A1234 \\
\hline $\begin{array}{l}\text { Garment style } \\
\text { development }\end{array}$ & $\mathrm{A} 111, \mathrm{~A} 114, \mathrm{~A} 121, \mathrm{~A} 1221, \mathrm{~A} 1222, \mathrm{~A} 1223$ \\
\hline $\begin{array}{l}\text { Marker making } \\
\text { and cutting }\end{array}$ & $\begin{array}{l}\text { A1412, A1421, A421, A422, A423, A5132, A5133, A51311, A51312, } \\
\text { A51313 }\end{array}$ \\
\hline $\begin{array}{l}\text { Sewing and } \\
\text { Assembly }\end{array}$ & $\mathrm{A} 1422, \mathrm{~A} 534, \mathrm{~A} 53241, \mathrm{~A} 53242, \mathrm{~A} 53244$ \\
\hline Cost estimation & A131 \\
\hline Quality control & $\begin{array}{l}\text { A1423, A1424, A143, A211, A212, A213, A3431, A3432, A3433, A3434, } \\
\text { A5141, A5142, A5143, A } 53243, \text { A5331, A5332, A } 541, \text { A542, A543, A544 }\end{array}$ \\
\hline $\begin{array}{l}\text { Manufacturing } \\
\text { planning }\end{array}$ & $\mathrm{A} 15, \mathrm{~A} 331, \mathrm{~A} 332, \mathrm{~A} 333, \mathrm{~A} 334, \mathrm{~A} 335$ \\
\hline $\begin{array}{l}\text { Production } \\
\text { scheduling }\end{array}$ & A1411, A313, A43, A412, A52, A511, A5321, A5322, A5323 \\
\hline $\begin{array}{l}\text { Packing and } \\
\text { shipping }\end{array}$ & $\begin{array}{l}\text { A5333, A62, A63, A6411, A6412, A6413, A6414, A6421, A6422, A6423, } \\
\text { A643 }\end{array}$ \\
\hline $\begin{array}{l}\text { Material } \\
\text { procurement }\end{array}$ & $\mathrm{A} 221, \mathrm{~A} 222, \mathrm{~A} 223, \mathrm{~A} 342, \mathrm{~A} 3411, \mathrm{~A} 3412, \mathrm{~A} 3413, \mathrm{~A} 413$ \\
\hline $\begin{array}{l}\text { Manufacturing } \\
\text { resource } \\
\text { maintenance } \\
\end{array}$ & A231, A232, A233, A234 \\
\hline $\begin{array}{l}\text { Production } \\
\text { resource } \\
\text { allocation } \\
\end{array}$ & $\mathrm{A} 1413, \mathrm{~A} 312, \mathrm{~A} 512, \mathrm{~A} 531$ \\
\hline $\begin{array}{l}\text { Sales and } \\
\text { marketing }\end{array}$ & A112, A113, A132, A133, A32, A311, A411 \\
\hline $\begin{array}{l}\text { Inventory } \\
\text { maintenance }\end{array}$ & $\mathrm{A} 3441, \mathrm{~A} 3442, \mathrm{~A} 3443, \mathrm{~A} 3444, \mathrm{~A} 611, \mathrm{~A} 612, \mathrm{~A} 613, \mathrm{~A} 614$ \\
\hline
\end{tabular}




\section{APPENDIX C. MAPPING THE INFORMATION MODEL TO THE APS}

This appendix details how the AMA's information model maps to the set of APs specified by this paper. The information model is presented in the AMA report [Jay2] in separate pieces, or views. Each view is assigned a title that is descriptive of that particular view and is contained on one or two pages. Each page is identified by a number that is prefixed by the label "RMX." (The "page" numbers are not in consecutive order.) The page numbers are used to identify the views in the tables presented in this appendix. In addition, the entities of this information model are each assigned a number in the AMA, and these numbers are used to identify those entities in this appendix. The mapping indicates what information model views and what entities are incorporated by each of the APs.

Each table below shows the mapping for one of the APs. Each table is composed of three parts. The first part is the name of the AP; next are the numbers and corresponding titles for the information model views that have been matched with this AP; last are the entity numbers and the names of the entities that have been matched with this AP. The APs and their mapping follows:

Ready-to-wear pattern grading

\begin{tabular}{ll} 
Page Number & View Title \\
RMX4 & Fit and Grading Tables \\
RMX5 & Pattern Description \\
RMX10 & Pattern Grading \\
Entity Number & Entity Name \\
\hline 7 & size \\
11 & grade_table \\
12 & grade_rule \\
14 & pattern \\
15 & pattern_part \\
16 & grad_pat_part \\
110 & pat_grade_point \\
111 & grade_point
\end{tabular}

Made-to-measure pattern making

$\begin{array}{ll}\text { Page Number } & \text { View Title } \\ \text { RMX4 } & \text { Fit and Gradin } \\ \text { RMX5 } & \text { Pattern Descriptio } \\ \text { Entity Number } & \text { Entity Name } \\ 2 & \text { fit } \\ 7 & \text { size } \\ 10 & \text { measurement } \\ 14 & \text { pattern } \\ 15 & \text { pattern_part }\end{array}$


Garment style development

\begin{tabular}{|c|c|}
\hline $\begin{array}{l}\text { Page Number } \\
\text { RMX1 } \\
\text { RMX2 } \\
\text { RMX5 } \\
\text { RMX6, RMX7 } \\
\text { RMX13, RMX42 } \\
\text { RMX31 }\end{array}$ & $\begin{array}{l}\text { Yiew Title } \\
\text { Product Development and Description } \\
\text { Sample Garment Description } \\
\text { Pattern Description } \\
\text { Construction Detail } \\
\text { Material Description } \\
\text { Assignment of Fabric-Dependent Construction Materials }\end{array}$ \\
\hline $\begin{array}{l}\text { Entity Number } \\
1 \\
2 \\
3 \\
6 \\
7 \\
9 \\
13 \\
14 \\
15 \\
17 \\
18 \\
19 \\
20 \\
21 \\
22 \\
23 \\
34 \\
37 \\
38 \\
39 \\
40 \\
41 \\
46 \\
79 \\
81 \\
109\end{array}$ & $\begin{array}{l}\text { Entity_Name } \\
\text { style } \\
\text { fit } \\
\text { const_detail } \\
\text { fabric } \\
\text { size } \\
\text { sample_req_item } \\
\text { base_pattern } \\
\text { pattern } \\
\text { pattern_part } \\
\text { constr_det_item } \\
\text { const_feature } \\
\text { const__ft_item } \\
\text { const__opr } \\
\text { const_ff_mat } \\
\text { material } \\
\text { process_plan } \\
\text { material_variant } \\
\text { trim } \\
\text { tk_tag_label } \\
\text { closure } \\
\text { thread } \\
\text { accessory } \\
\text { prog_item } \\
\text { prog_material } \\
\text { color } \\
\text { style_concept }\end{array}$ \\
\hline
\end{tabular}

Marker making and cutting

$\begin{array}{ll}\begin{array}{ll}\text { Page Number } \\ \text { RMX16, RMX17 }\end{array} & \begin{array}{l}\text { View Title } \\ \text { Cut Order Planning } \\ \text { RMX18 }\end{array} \\ \begin{array}{ll}\text { Marker Making } \\ \text { Entity Number }\end{array} & \text { Entity Name } \\ 7 & \text { size } \\ 16 & \text { grad_pat_part } \\ 46 & \text { prog_item } \\ 48 & \text { production_order } \\ 49 & \text { size_scale } \\ 50 & \text { prod_order_item } \\ 51 & \text { marker }\end{array}$


scaled_section

marker_section

scaled_sec_part

scaled_group

spread_section

Sewing and assembly

$\begin{array}{ll}\text { Page Number } & \text { View Title } \\ \text { RMX6, RMX7 } & \text { Construction Detail } \\ \text { RMX26, RMX27 } & \text { Cut Package Preparation }\end{array}$

Entity Number Entity Name 3

17

18

19

20

21

22

28

34

48

72

74

78

constr_detail

constr_det_item

constr_feature

constr_ft_item

constr_opr

constr_ft_mat

material

garment_type

material_variant

production_order

scaled_group

prod_ord_mat

garment_unit

100

gar_subassembly

Cost estimation

$\begin{array}{ll}\text { Page Number } & \text { View_Title } \\ \text { RMX2 } & \text { Sample Garment Desction } \\ \text { RMX3 } & \text { Sample Production Sch } \\ \text { RMX5 } & \text { Pattern Description } \\ \text { RMX6, RMX7 } & \text { Construction Detail } \\ \text { RMX13, RMX42 } & \text { Material Description } \\ & \\ \text { Entity Number } & \text { Entity_Name } \\ 3 & \text { constr_detail } \\ 4 & \text { customer } \\ 5 & \text { sam_prod_assgnmt } \\ 6 & \text { fabric } \\ 7 & \text { size } \\ 8 & \text { sample_req } \\ 9 & \text { sample_req_item } \\ 14 & \text { pattern } \\ 15 & \text { pattern_part } \\ 17 & \text { constr_det_item } \\ 18 & \text { const_feature } \\ 19 & \text { constr_ft_item }\end{array}$




$\begin{array}{ll}20 & \text { constr_opr } \\ 21 & \text { const_ft_mat } \\ 22 & \text { material } \\ 34 & \text { material_variant } \\ 37 & \text { trim } \\ 38 & \text { tk_tag_label } \\ 39 & \text { closure } \\ 40 & \text { thread } \\ 41 & \text { accessory } \\ 81 & \text { color } \\ 94 & \text { sal_employee } \\ 109 & \text { style_concept }\end{array}$

Quality control

$\begin{array}{ll}\text { Page Number } & \text { View_Title } \\ \text { RMX2 } & \text { Sample Garment Description } \\ \text { RMX33, RMX34 } & \text { Quality Control } \\ \text { Entity_Number } & \text { Entity_Name } \\ 4 & \text { customer } \\ 8 & \text { sample_req } \\ 82 & \text { qc_procedure } \\ 83 & \text { quality_report } \\ 84 & \text { quality_rep_item } \\ 85 & \text { fab_insp_report } \\ 86 & \text { fab_test_report } \\ 87 & \text { mat_insp_report } \\ 88 & \text { mat_test_report } \\ 89 & \text { fg_audit_report } \\ 90 & \text { fg_test_report }\end{array}$

Manufacturing planning

Page Number

RMX6, RMX7

$\mathrm{RMX8}$

$\mathrm{RMX9}$

RMX15

$\mathrm{RMX22}$

$\mathrm{RMX23}$

$\mathrm{RMX} 40$

\section{Entity Number}

3

7

17

18

19

20
Yiew Title

Construction Detail

Process Planning

Production Garment Description

Production Planning

Manufacturing Resources - Equipment

Manufacturing Resources - Human

Manufacturing Equipment Capability
Entity Name
constr_detail
size
constr_det_item
constr_feature
constr_ft_item
constr_opr 


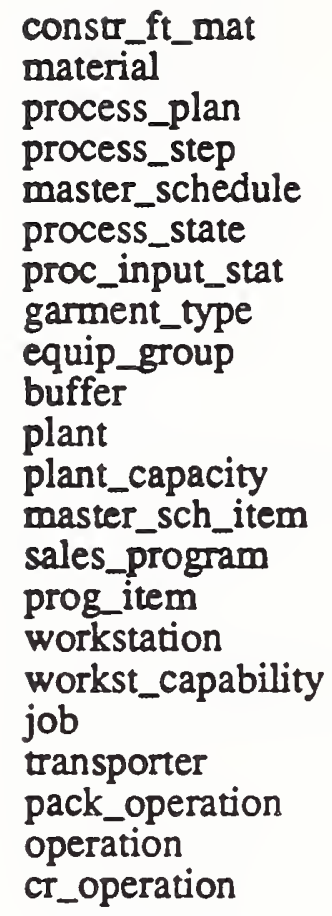

Production scheduling

$\begin{array}{ll}\text { Page Number } & \text { View_Title } \\ \text { RMX3 } & \text { Sample Production Sc } \\ \text { RMX8 } & \text { Process Planning } \\ \text { RMX14 } & \text { Sales Program Desc } \\ \text { RMX15 } & \text { Production Planning } \\ \text { RMX24, RMX25 } & \text { Cutting Room Sched } \\ \text { RMX28 } & \text { Manufacturing Plant } \\ & \\ \text { Entity Number } & \text { Entity Name } \\ 1 & \text { style } \\ 5 & \text { sam_prod_assgnmt } \\ 6 & \text { fabric } \\ 8 & \text { sample_req } \\ 20 & \text { const_opr } \\ 23 & \text { process_plan } \\ 24 & \text { process_step } \\ 26 & \text { process_state } \\ 27 & \text { proc_input_stat } \\ 44 & \text { master_sch_item } \\ 45 & \text { sales_program } \\ 47 & \text { prog_del_schedule } \\ 48 & \text { production_order } \\ 62 & \text { workstation } \\ 64 & \text { operator } \\ 67 & \text { cut_rm_schedule } \\ 68 & \text { cut_rm_sch_item } \\ 69 & \text { cr_assignment } \\ & \end{array}$


cr_oper_assgnmt

plant_schedule

plant_sch_item

92

sam_dept_sch

95

sam_dep_sch_item

108

irreg_style

cr_operation

Packing and shipping

Page Number

RMX20

View Title

$\mathrm{RMX} 21$

Finished Goods Warehousing

RMX38, RMX39

Shipping Order Description

Entity Number

4

28

55

57

58

59

60

64

94

95

96

97

101

102

103

104

105

106

Entity Name

customer

garment_type

manifest

fg_carton

shipping order

shipping_loc

ship_order_item

operator

sal_employee

irreg_style

irreg_fg_carton

reg_fg_carton

cons_ship_order

pack_schedule

pack_sch_item

pack_assignment

pack_op_assgnmt

pack_operation

Material procurement

Page Number

RMX11; RMX 12

View Title

$\mathrm{RMX13}, \mathrm{RMX} 42$

Material Procurement

Material Description

$\begin{array}{ll}\text { Entity Number } & \text { Entity Name } \\ 6 & \text { fabric } \\ 22 & \text { material } \\ 31 & \text { material_vendor } \\ 32 & \text { mat_purchase_order } \\ 33 & \text { mat_po_item } \\ 34 & \text { mat_variant } \\ 35 & \text { stored_item } \\ 36 & \text { material_location }\end{array}$


trim

$$
\begin{aligned}
& \text { tk_tag_label } \\
& \text { closure } \\
& \text { thread } \\
& \text { accessory } \\
& \text { production_order } \\
& \text { color } \\
& \text { material_source }
\end{aligned}
$$

Manufacturing resource maintenance

Page Number

RMX15

RMX22

$\mathrm{RMX23}$

RMX40

Entity Number

$$
20
$$

29

30

42

43

61

62

63

64

65

66

71

94

106

107

108
View Title

Production Planning

Manufacturing Resources - Equipment

Manufacturing Resources - Human

Manufacturing Equipment Capability

\section{Entity Name}

constr_opr

equip_group

buffer

plant

plant_capacity

department

workstation

workst_capability

operator

operator_skill

job

transporter

sal_employee

pack_operation

operation

cr_operation

Production resource allocation

Page Number

RMX29, RMX30

Entity Number

24

29

64

73

76

77

80

94
View Title

Manufacturing Resource Assignment

Entity Name

process_step

equip_group

operator

assigned_oper

plant_sch_item

assigned_equip

work_assignment

sal_employee 
Sales and marketing

Page Number

RMX2

RMX14

RMX15

RMX36

Entity Number

1

4

6

7

8

9

44

45

46

47

95

99

109
View Title

Sample Garment Description

Sales Program Description

Production Planning

Customer Interaction

Inventory Maintenance

Page Number

RMX19, RMX20

Entity Number

28

48

55

56

57

78

95

96

97
Entity Name

style

customer

fabric

size

sample_req

sam_req_item

master_sch_item

sales_program

prog_item

prog_del_schedule

irreg_style

customer_ing

style_concept

View Title

Finished Goods Warehousing

Entity Name

garment_type

production_order

manifest

fg_storage_loc

fg_carton

garment_unit

irreg_style

irreg_fg_carton

reg_fg_carton 
The mapping presented in this appendix is the reverse of that in Appendix C. The APs are mapped to the information model views in Appendix D.1. The APs are mapped to the entities in Appendix D.2.

\section{D.1. Mapping the APs to the Information Model Views}

Each view of the information model is listed by its RMX number (or two) in the left column, and the list of associated APs in the right.

\begin{tabular}{|c|c|}
\hline $\begin{array}{l}\text { AMA Information } \\
\text { Model Vierg }\end{array}$ & Associated APs \\
\hline $\mathrm{RMX1}$ & style \\
\hline $\mathrm{RM} \times 2$ & style, cost, sales, quality \\
\hline $\mathrm{RMX3}$ & $\begin{array}{l}\text { scheduling } \\
\text { sing }\end{array}$ \\
\hline $\mathrm{RMX} 4$ & grading, pattern \\
\hline RMX5 & grading, pattern, style, cost \\
\hline $\mathrm{RM} \times 6, \mathrm{RMX7}$ & style, assembly, planning, cost \\
\hline RMX8 & planning, scheduling \\
\hline RMX9 & planning \\
\hline $\mathrm{RMX10}$ & grading \\
\hline $\mathrm{RMX} 11, \mathrm{RMX} 12$ & procurement \\
\hline $\begin{array}{l}\mathrm{RMX} 13, \mathrm{RMX} 42 \\
\mathrm{RMX14}\end{array}$ & style, cost, procurement \\
\hline $\begin{array}{l}\text { RMX14 } \\
\text { RMX15 }\end{array}$ & $\begin{array}{l}\text { scheduling, sales } \\
\text { planning, scheduling, resources, sales }\end{array}$ \\
\hline $\mathrm{RMX16,RMX17}$ & marker \\
\hline $\mathrm{RMX18}$ & marker \\
\hline $\mathrm{RMX} 19, \mathrm{RMX20}$ & inventory, packing \\
\hline $\mathrm{RMX21}$ & packing \\
\hline $\mathrm{RMX22}$ & planning, resources \\
\hline $\mathrm{RMX23}$ & planning, resources \\
\hline $\mathrm{RMX24,} R M \times 25$ & scheduling \\
\hline $\begin{array}{l}\mathrm{RMX26}, \mathrm{RMX27} \\
\mathrm{RMX} 28\end{array}$ & assembly \\
\hline RMX28 & scheduling \\
\hline $\mathrm{RMX29,} \mathrm{RMX30}$ & allocation \\
\hline RMX31 & style \\
\hline $\mathrm{RMX33,} R \mathrm{MX} 34$ & quality \\
\hline X36 & sales \\
\hline $\mathrm{RMX38,} \mathrm{RMX39}$ & packing \\
\hline$\times 40$ & planning, re \\
\hline
\end{tabular}

\section{D.2. Mapping the APs to the Entities}

Each entity is listed by its name in the left column, its $\mathbb{D}$ number in the second column, and the list of associated APs in the right column.

\begin{tabular}{|c|c|c|}
\hline $\begin{array}{l}\text { AMA Entity Name } \\
\text { accessory } \\
\text { assigned_equip } \\
\text { assigned_oper } \\
\text { base_pattern } \\
\text { buffer }\end{array}$ & $\begin{array}{l}\text { ID } \\
41 \\
77 \\
73 \\
13 \\
30\end{array}$ & $\begin{array}{l}\text { AP Name } \\
\text { style, cost, procurement } \\
\text { allocation } \\
\text { allocation } \\
\text { style } \\
\text { planning, resources }\end{array}$ \\
\hline
\end{tabular}




closure
color
cons_ship_order
constr_det_item
const_detail
constr_feature
constr_ft_item
constr_ft_mat
const_opr
customer
customer_inq
cut_rm_sch_item
cut_rm_schedule
cr_assignment
cr_oper_assgnmt
cr_operation
department
equip_group
fab_insp_report
fab_ttest_report
fabric
fg_audit_report
fg_carton
fg_storage_loc
fg_test_report
fit
gar_subassembly
garment_type
garment_unit
grad_pat_part
grade_point
grade_rule
grade_table
irreg_fg_carton
irreg_style
job
manifest
marker
marker_section
master_sch_item
master_schedule
mat_insp_report
mat_po_item
mat_purchase_order
mat_test_report
material
material_location
material_source
material_variant
material_vendor
measurement
operation
operator
operator_skill

style, cost, procurement style, cost, procurement packing style, assembly, planning, cost style, assembly, planning, cost style, assembly, planning, cost style, assembly, planning, cost style, assembly, planning, cost style, assembly, planning, cost
style, assembly, planning, cost, cost, packing, sales, quality

$$
\text { sales }
$$

scheduling

scheduling

scheduling

scheduling

planning, scheduling, resources

\section{resources}

planning, resources, allocation

quality

quality

style, cost, scheduling, sales, procurement

\section{quality} packing, inventory inventory quality pattern, style assembly planning, packing, inventory, assembly inventory, assembly grading, marker grading grading grading packing, inventory scheduling, packing, sales, inventory planning, resources packing, inventory marker marker planning, scheduling, sales planning quality procurement procurement quality style, assembly, planning, cost, procurement procurement procurement style, assembly, cost, procurement procurement pattern planning, resources scheduling, packing, resources, allocation resources 


\begin{tabular}{|c|c|c|}
\hline $\begin{array}{l}\text { pack_assignment } \\
\text { pack_op_assgnmt } \\
\text { pack_operation } \\
\text { pack_sch_item } \\
\text { pack_schedule } \\
\text { pat_grade_point } \\
\text { pattern } \\
\text { pattern_part } \\
\text { plant } \\
\text { plant_capacity } \\
\text { plant_sch_item } \\
\text { plant_schedule } \\
\text { proc_input_stat } \\
\text { process_plan } \\
\text { process_state } \\
\text { process_step } \\
\text { prod_order_item } \\
\text { prod_ord_mat } \\
\text { production_order } \\
\text { prog_del_schedule } \\
\text { prog_item } \\
\text { program_material } \\
\text { quality_report } \\
\text { quality_rep_item } \\
\text { qc_procedure } \\
\text { reg_fg_carton } \\
\text { sal_employee } \\
\text { sales_program } \\
\text { sam_dept_sch } \\
\text { sam_dept_sch_item } \\
\text { sam_prod_assgnmt } \\
\text { sam_req_item } \\
\text { sample_req } \\
\text { scaled_group } \\
\text { scaled_sec_part } \\
\text { scaled_section } \\
\text { ship_order_item } \\
\text { shipping_loc } \\
\text { shipping_order } \\
\text { size } \\
\text { size_scale } \\
\text { spread_section } \\
\text { stored_item } \\
\text { style } \\
\text { style_concept } \\
\text { thread } \\
\text { tk_tag_label } \\
\text { transporter } \\
\text { trim } \\
\text { work_assignment } \\
\text { workst_capability } \\
\text { workstation } \\
\text { wation }\end{array}$ & $\begin{array}{l}104 \\
105 \\
106 \\
103 \\
102 \\
110 \\
14 \\
15 \\
42 \\
43 \\
76 \\
75 \\
27 \\
23 \\
26 \\
24 \\
50 \\
74 \\
48 \\
47 \\
46 \\
79 \\
83 \\
84 \\
82 \\
97 \\
94 \\
45 \\
91 \\
92 \\
5 \\
9 \\
8 \\
72 \\
54 \\
52 \\
60 \\
59 \\
58 \\
7 \\
49 \\
98 \\
35 \\
1 \\
109 \\
40 \\
38 \\
71 \\
37 \\
80 \\
63 \\
62\end{array}$ & $\begin{array}{l}\text { packing } \\
\text { packing } \\
\text { packing, planning, resources } \\
\text { packing } \\
\text { packing } \\
\text { grading } \\
\text { grading, pattern, style, cost } \\
\text { grading, pattern, style, cost } \\
\text { planning, resources } \\
\text { planning, resources } \\
\text { scheduling, allocation } \\
\text { scheduling } \\
\text { planning, scheduling } \\
\text { style, planning, scheduling } \\
\text { planning, scheduling } \\
\text { planning, scheduling, allocation } \\
\text { marker } \\
\text { assembly } \\
\text { marker, assembly, scheduling, procurement, inventory } \\
\text { scheduling, sales } \\
\text { style, marker, planning, sales } \\
\text { style } \\
\text { quality } \\
\text { quality } \\
\text { quality } \\
\text { packing, inventory } \\
\text { cost, packing, resources, allocation } \\
\text { planning, scheduling, sales } \\
\text { scheduling } \\
\text { scheduling } \\
\text { scheduling, cost } \\
\text { style, cost. sales } \\
\text { cost, scheduling, sales, quality } \\
\text { marker, assembly } \\
\text { marker } \\
\text { marker } \\
\text { packing } \\
\text { packing } \\
\text { packing } \\
\text { grading, pattern, style, marker, cost, planning, sales } \\
\text { marker } \\
\text { marker } \\
\text { procurement } \\
\text { style, scheduling, sales } \\
\text { style, cost, sales } \\
\text { style, cost, procurement } \\
\text { style, cost, procurement } \\
\text { planning, resources } \\
\text { style, cost, procurement } \\
\text { allocation } \\
\text { planning, resources } \\
\text { planning, scheduling, resources } \\
\text { al }\end{array}$ \\
\hline
\end{tabular}



